\title{
Candida heliconiae sp. nov., Candida picinguabensis sp. nov. and Candida saopaulonensis sp. nov., three ascomycetous yeasts from Heliconia velloziana (Heliconiaceae)
}

\author{
Correspondence \\ Carla C. C. Ruivo \\ carlaccr@yahoo.com.br
}

\author{
Carla C. C. Ruivo, ${ }^{1}$ Marc-André Lachance, ${ }^{2}$ Carlos A. Rosa, ${ }^{3}$ \\ Maurício Bacci, $\mathrm{Jr}^{1}$ and Fernando C. Pagnocca ${ }^{1}$

\begin{abstract}
${ }^{1}$ Centro de Estudos de Insetos Sociais e Departamento de Bioquímica e Microbiologia, Universidade Estadual Paulista - Unesp, CP 199, Rio Claro, SP, 13506-900, Brazil

${ }^{2}$ Department of Biology, University of Western Ontario, London, Ontario N6A 5B7, Canada

${ }^{3}$ Departamento de Microbiologia - ICB, CP 486, Universidade Federal de Minas Gerais, Belo Horizonte, MG, 31270-901, Brazil
\end{abstract}

\begin{abstract}
Strains belonging to three novel yeast species, Candida heliconiae (four isolates), Candida picinguabensis (three isolates) and Candida saopaulonensis (two isolates), were recovered in the year 2000 from water of flower bracts of Heliconia velloziana L. Emigd. (Heliconiaceae) found in a forest ecosystem site in an Atlantic rainforest of south-eastern Brazil. C. picinguabensis and $C$. saopaulonensis were nearly identical in morphology and physiology, but sequence divergence in the D1/D2 domain of the large-subunit rDNA indicated that they should be regarded as different species. They belong to the Metschnikowiaceae clade. C. heliconiae had affinities to Pichia mexicana and related species, but was genetically isolated from all currently accepted species in that group. The type strains are C. heliconiae UNESP $00-91 \mathrm{C} 1^{\top}(=\mathrm{CBS}$ $10000^{\top}=$ NRRL $\left.Y-27813^{\top}\right)$, C. picinguabensis UNESP 00-89 ${ }^{\top}\left(=\mathrm{CBS} 9999^{\top}=\mathrm{NRRL}\right.$ Y-27814 $\left.{ }^{\top}\right)$ and C. saopaulonensis UNESP $00-99^{\top}\left(=\right.$ CBS $10001^{\top}=$ NRRL Y $\left.-27815^{\top}\right)$.
\end{abstract}

The family Heliconiaceae contains a single genus, Heliconia L., with approximately 250 species dispersed in neotropical areas from the north of Mexico to the south of Brazil (Santos, 1978; Dahlgren et al., 1985; Kress, 1990). A small paleotropical group, with eight species, occurs in islands of the South Pacific (Tomlinson, 1969; Kress, 1985). Approximately 40 Brazilian species are known. They occur mostly in the Amazon basin and in the Atlantic coastal forest (Kress, 1990). Heliconia velloziana is an endemic species from the Atlantic Forest and occurs from the south-east to the south of Brazil (Mello-Filho, 1975; Santos, 1978; Citadini-Zanette \& Baptista, 1989). One characteristic of the genus Heliconia is rapidly decaying floral parts enclosed by massive, surviving bracts. The nectar in the bracts is thought to be the site of development of communities of yeasts and bacteria (Schnittler \& Stephenson, 2002). In this paper, we describe the occurrence of the novel yeast species Candida heliconiae, Candida picinguabensis and Candida saopaulonensis in Heliconia velloziana.

The GenBank/EMBL/DDBJ accession numbers for the large-subunit rRNA gene sequences of strains UNESP 00-91C $1^{\top}$, UNESP 00-89 ${ }^{\top}$ and UNESP 00-99 ${ }^{\top}$ are AY566406, AY566407 and AY695398, respectively.

\section{Yeast isolation and characterization}

Four strains of $C$. heliconiae, three of $C$. picinguabensis and two of $C$. saopaulonensis were isolated from the water of flower bracts of Heliconia velloziana collected in the Picinguaba area, an Atlantic rainforest site in the 'Serra do Mar' State Park in São Paulo State, Brazil ( $23^{\circ} 22^{\prime}$ S $\left.44^{\circ} 48^{\prime} \mathrm{W}\right)$. This State Park contains one of the largest continuous areas of the remaining Brazilian Atlantic Forest in eastern São Paulo State, and is located $230 \mathrm{~km}$ from the city of São Paulo. Collections were made from 14 plants during spring (September) 2000. The water accumulated in the bract was stirred with a sterile loop that was then used to streak-inoculate three plates of YM agar (1\% glucose, $0.5 \%$ peptone, $0.3 \%$ malt extract, $2 \%$ agar) containing $100 \mathrm{mg}$ chloramphenicol $\mathrm{l}^{-1}$ (Trindade et al., 2002). The plates were incubated at $25^{\circ} \mathrm{C}$ for 5 days. Selected representative colonies were purified and maintained on YM agar slants at $4{ }^{\circ} \mathrm{C}$ and at $-80^{\circ} \mathrm{C}$. The yeasts were characterized by using standard methods (Yarrow, 1998) and their identification was carried out using the keys of Kurtzman \& Fell (1998) and the CD-ROM Yeasts of the World (Boekhout et al., 2002).

\section{DNA sequence analysis}

Yeast DNA was extracted and purified according to a protocol recommended for the Genomic Prep. Cells and Tissue 
DNA isolation kit (Amersham Pharmacia Biotech). The divergent D1/D2 domains of the large-subunit rDNA were symmetrically amplified with primers NL-1 and NL4 (O'Donnell, 1993). Each PCR was performed with the Ready-To-Go kit (Amersham Pharmacia Biotech), according to the manufacturer's recommendations.

The sequence products were resolved in an ABI Prism 377 DNA sequencer (Applied Biosystems) at the Centro de Estudos de Insetos Sociais - UNESP, Rio Claro, São Paulo, Brazil. Alternatively, the DNA was amplified directly from whole cells and sequenced as described by Lachance et al. (1999). Sequence alignment and tree construction were done with the program DNAMAN 4.1 (Lynnon Biosoft).

\section{Species delineation, classification and ecology}

All strains were examined after growth on common sporulation media, either alone or in pairwise mixtures. Conjugation or ascus formation was not observed. In the absence of a sexual cycle, species delineation relied on sequence divergence. Based on the analysis of the large-subunit rDNA D1/ D2 domains, C. picinguabensis and C. saopaulonensis represent sister species with affinities to the Metschnikowiaceae clade. The sequences of the two taxa differed from each other by 18 substitutions and three gaps, which supports the hypothesis that they represent separate species (Kurtzman \& Robnett, 1998). Physiologically, the two species differed only in the assimilation of galactose and the ability to grow in the presence of $10 \mu \mathrm{g}$ cycloheximide $\mathrm{ml}^{-1}$. The species shown in Fig. 1(a) are representatives of neighbouring clades, chosen to identify the approximate phylogenetic position of the novel species. A reliable connection with any known species within the Metschnikowiaceae clade could not be established, although a weak link with Metschnikowia and related Candida species found in beetles and other insects of morning glories was apparent. C. heliconiae has no clearly identifiable sister species and occupies a basal position in a clade that contains Pichia mexicana and related Pichia or Candida species. The species in Fig. 1(b) were selected to assist in localizing C. heliconiae phylogenetically. A weak connection was found with Candida sinolaborantium and other species known to be associated with the plant-insect interface.

Although the newly described species were isolated from water accumulated in bracts of Heliconia velloziana, it cannot be assumed that they are associated only with this plant, as Heliconia species are visited by hummingbirds attracted by the flower's nectar (Stiles, 1975). In addition to the novel species described herein, other yeasts isolated from the same substrates included Candida azyma, Candida boidinii, Candida pseudointermedia, Candida restingae, Candida silvae, Debaryomyces spp., Hanseniaspora uvarum, Kluyveromyces sp., Kodamaea sp., Metschnikowia koreensis and Metschnikowia sp., which are often found in flowers (Rosa et al., 1999; Hong et al., 2001). As C. picinguabensis and C. saopaulonensis have similar physiologies and morphologies, they are expected to occur in similar microhabitats. Our results suggest that these novel species are nectar-inhabiting yeasts. (a)

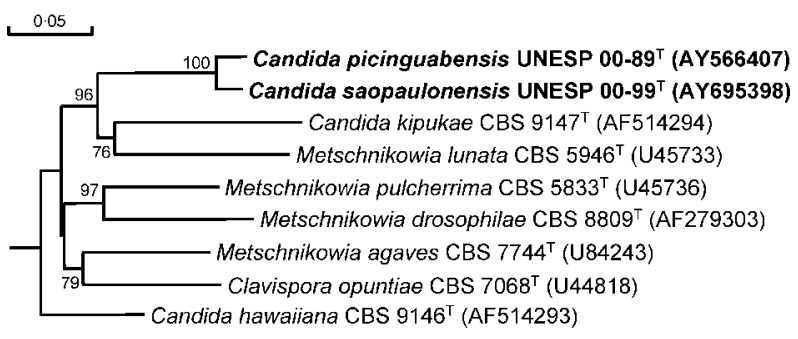

(b)

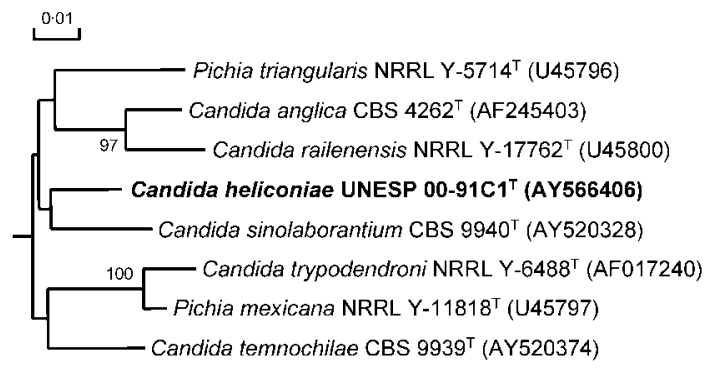

Fig. 1. Neighbour-joining dendrograms, based on sequences of the D1/D2 domains of the large-subunit rDNA, depicting the approximate phylogenetic positions of $C$. picinguabensis and C. saopaulonensis (a) and C. heliconiae (b). Bootstrap values greater than $75 \%$, determined from 1000 interactions, are shown. Bars, sequence divergence with Kimura's two-parameter correction. Root placement was based on the inclusion of Schizosaccharomyces pombe (NRRL Y-12796' ${ }^{\top}$, GenBank accession no. U40085; not shown) as an outgroup.

\section{Latin diagnosis of Candida heliconiae Ruivo, Pagnocca, Lachance et Rosa sp. nov.}

In medio liquido post dies tres ad $25^{\circ} \mathrm{C}$, cellulae globosae aut ovoidae, singulae aut binae $(3-5 \cdot 5 \times 3-5 \mu \mathrm{m})$. Cultura in agaro extracta malti et levidinis continente post 4 dies ad $25^{\circ} \mathrm{C}$, albida cremae et butyrosa. In agaro farinae Zea mays post dies 14 pseudomycelium non formatur. Asci non formantur. Glucosum fermentatur. Glucosum, galactosum, L-sorbosum, sucrosum, maltosum, cellobiosum, melezitosum, D-xylosum, L-arabinosum (variabile), D-arabinosum, Dglucosaminum (variabile), N-acetyl-D-glucosaminum, ethanolum, glycerolum, ribitolum, mannitolum, glucitolum, methyl $\alpha$-D-glucosidium, acidum gluconicum (lente), salicinum (exigue), et glucono- $\delta$-lactonum assimilantur. Non assimilantur trehalosum, lactosum, melibiosum, raffinosum, inulinum, amylum solubile, D-ribosum, L-rhamnosum, methanolum, erythritolum, galactitolum, acidum lacticum, acidum succinicum, acidum citricum, myo-inositolum, n-hexadecanum (lente), 2-keto-D-gluconatum, 5-keto-Dgluconatum et xylitolum. L-Lysinum, ethylaminum et cadaverinum assimilantur at non natrium nitrosum nec natrium nitricum. Augmentum in $35^{\circ} \mathrm{C}$, at non $37^{\circ} \mathrm{C}$. Ureum non finditur. Diazonium caeruleum B negativum. Materia amyloidea non formantur. Non crescit agaro extrato fermenti 
confecto 50 partes glucosi per centum. Habitat aqua et Heliconia velloziana L. Emigd. (Heliconiaceae). Typus stirps UNESP 00-91C1 ${ }^{\mathrm{T}}$. In collectione zymotica Centraalbureau voor Schimmelcultures, Trajectum ad Rhenum, sub no. CBS $10000^{\mathrm{T}}$, typus stirps deposita est.

\section{Description of Candida heliconiae Ruivo, Pagnocca, Lachance \& Rosa sp. nov.}

Candida heliconiae (he.li.co'ni.ae. N.L. gen. n. heliconiae of Heliconia velloziana, referring to the plant from which the species was isolated).

In yeast extract $(0 \cdot 5 \%)$ glucose $(2 \%)$ broth after 3 days at $25^{\circ} \mathrm{C}$, cells occur singly or in budding pairs. Cells are spheroidal to ovoid $(3-5 \cdot 5 \times 3-5 \mu \mathrm{m})$. Buds are produced multilaterally (Fig. 2a). On YM agar after 4 days at $25^{\circ} \mathrm{C}$, colonies are cream-coloured or white, low-convex, smooth and butyrous. After 2 weeks in Dalmau plate culture on cornmeal agar, pseudomycelium or true mycelium is not formed. Glucose fermentation is complete after $2-5$ days. The carbon compounds glucose, galactose, L-sorbose, sucrose, maltose, cellobiose, melezitose, D-xylose, L-arabinose (variable), D-arabinose, D-glucosamine (variable), $N$-acetyl-Dglucosamine, ethanol, glycerol, ribitol, mannitol, glucitol, methyl $\alpha$-D-glucoside, D-gluconic acid (slow), salicin (weak) and glucono- $\delta$-lactone are assimilated. No growth occurs on trehalose, lactose, melibiose, raffinose, inulin, starch, Dribose, L-rhamnose, methanol, erythritol, galactitol, DL-lactic acid, succinic acid, citric acid, myo-inositol, n-hexadecane, 2-keto-D-gluconate, 5-keto-D-gluconate or xylitol. Assimilation of nitrogen compounds: L-lysine, ethylamine and cadaverine are positive; nitrate and nitrite are negative. Growth at $35^{\circ} \mathrm{C}$ is positive and negative at $37^{\circ} \mathrm{C}$. Acid formation on chalk agar is weak or absent. Urease activity and Diazonium blue $\mathrm{B}$ reaction are negative. Production of amyloid compounds is negative. Growth on $50 \%$ glucose/yeast extract agar is negative. Growth on YM agar with $10 \% \mathrm{NaCl}$ is negative. Growth in the presence of 10 and $100 \mu \mathrm{g}$ cycloheximide $\mathrm{ml}^{-1}$ is positive. Growth in the presence of $1 \%$ acetic acid is negative.

The type strain, UNESP 00-91C1 ${ }^{\mathrm{T}}$, was isolated from water accumulated in flower bracts of Heliconia velloziana in Brazil. It has been deposited in the collection of the Yeast Division of the Centraalbureau voor Schimmelcultures, Utrecht, The Netherlands, as strain CBS $10000^{\mathrm{T}}$ (=NRRL $\left.\mathrm{Y}-27813^{\mathrm{T}}\right)$.

\section{Latin diagnosis of Candida picinguabensis Ruivo, Pagnocca, Lachance et Rosa sp. nov.}

In medio liquido post dies tres ad $25^{\circ} \mathrm{C}$, cellulae globosae, singulae aut binae $(3-7 \times 4-8 \mu \mathrm{m})$. Cultura in agaro extracta malti et levidinis continente post 4 dies ad $25^{\circ} \mathrm{C}$, albida cremae et butyrosa. In agaro farinae Zea mays post dies 14 pseudomycelium non formatur. Asci non formantur. Glucosum fermentatur. Glucosum, L-sorbosum, sucrosum, maltosum, trehalosum, melezitosum, D-xylosum, ethanolum, ribitolum, mannitolum, glucitolum, methyl $\alpha$-D-glucosidium, acidum gluconicum (variabile), acidum lacticum (lente), acidum succinicum (exigue), acidum citricum (exigue), $\mathrm{n}$-hexadecanum (lente), glucono- $\delta$-lactonum, 2-keto-Dgluconatum et xylitolum assimilantur. Non assimilantur galactosum, cellobiosum, lactosum, melibiosum, raffinosum, inulinum, amylum solubile, L-arabinosum, D-arabinosum, D-ribosum, L-rhamnosum, D-glucosaminum, N-acetyl-Dglucosaminum, methanolum, glycerolum, erythritolum, galactitolum, salicinum, myo-inositolum et 5-keto-D-gluconatum. L-Lysinum, ethylaminum et cadaverinum assimilantur at non natrium nitrosum nec natrium nitricum. Augmentum in $35^{\circ} \mathrm{C}$, at non $37^{\circ} \mathrm{C}$. Ureum non finditur. Diazonium caeruleum B negativum. Materia amyloidea non formantur. Crescit agaro extrato fermenti confecto 50 partes glucosi per centum et lente. Non crescit in medio $100 \mu \mathrm{g} \mathrm{ml}^{-1}$ cycloheximido addito. Habitat aqua et Heliconia velloziana L. Emigd. (Heliconiaceae). Typus stirps UNESP 00-89 ${ }^{\mathrm{T}}$. In collectione zymotica Centraalbureau voor Schimmelcultures,
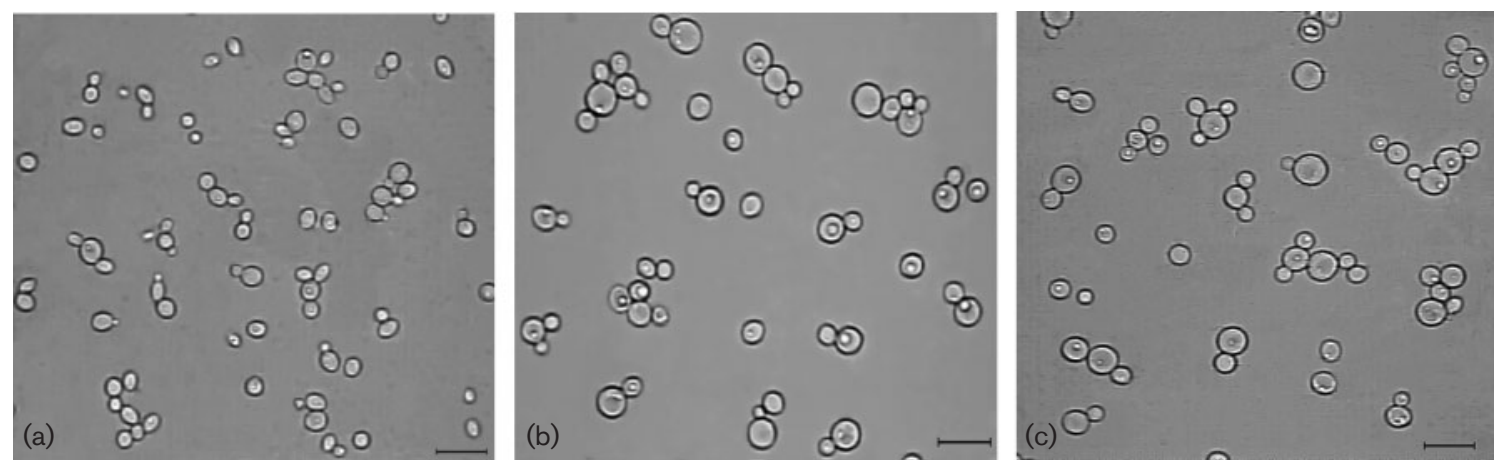

Fig. 2. Photomicrographs of cells of $C$. heliconiae strain UNESP $00-91 C 1^{\top}$ (a), C. picinguabensis strain UNESP $00-89^{\top}$ (b) and C. saopaulonensis UNESP $00-99^{\top}$ (c) in yeast extract, glucose broth after 3 days at $25^{\circ} \mathrm{C}$. Bars, $10 \mu \mathrm{m}$. 
Trajectum ad Rhenum, sub no. CBS $9999^{\mathrm{T}}$, typus stirps deposita est.

\section{Description of Candida picinguabensis Ruivo, Pagnocca, Lachance \& Rosa sp. nov.}

Candida picinguabensis (pi.ci.n.gua'ben.sis. N.L. fem. adj., picinguabensis pertaining to Picinguaba area, referring to the locality where the species was isolated).

In yeast extract $(0.5 \%)$ glucose $(2 \%)$ broth after 3 days at $25^{\circ} \mathrm{C}$, cells occur singly or in budding pairs. Cells are spheroidal $(3-7 \times 4-8 \mu \mathrm{m})$. Buds are produced multilaterally (Fig. 2b). On YM agar after 4 days at $25^{\circ} \mathrm{C}$, colonies are cream-coloured or white, low-convex, smooth and butyrous. After 2 weeks in Dalmau plate culture on cornmeal agar, pseudomycelium or true mycelium is not formed. Glucose fermentation is complete after 2-5 days. The carbon compounds glucose, L-sorbose, sucrose, maltose, trehalose, melezitose, D-xylose, ethanol, ribitol, mannitol, glucitol, methyl $\alpha$-D-glucoside, D-gluconic acid (variable), DL-lactic acid (slow), succinic acid (weak), citric acid (weak), n-hexadecane (slow), glucono- $\delta$-lactone, 2keto-D-gluconate and xylitol are assimilated. No growth occurs on galactose, cellobiose, lactose, melibiose, raffinose, inulin, starch, L-arabinose, D-arabinose, D-ribose, Lrhamnose, D-glucosamine, $\mathrm{N}$-acetyl-D-glucosamine, methanol, glycerol, erythritol, galactitol, salicin, myo-inositol or 5-keto-D-gluconate. Assimilation of nitrogen compounds: L-lysine, ethylamine and cadaverine are positive; nitrate and nitrite are negative. Growth at $35^{\circ} \mathrm{C}$ is positive and negative at $37^{\circ} \mathrm{C}$. Acid formation on chalk agar is positive. Urease activity and Diazonium blue $\mathrm{B}$ reaction are negative. Production of amyloid compounds is negative. Growth on $50 \%$ glucose/yeast extract agar is slow. Growth on YM agar with $10 \% \mathrm{NaCl}$ is negative. Growth in the presence of $10 \mu \mathrm{g}$ cycloheximide $\mathrm{ml}^{-1}$ is positive and negative in $100 \mu \mathrm{g}$ cycloheximide $\mathrm{ml}^{-1}$. Growth in the presence of $1 \%$ acetic acid is negative.

The type strain, UNESP $00-89^{\mathrm{T}}$, was isolated from water accumulated in flower bracts of Heliconia velloziana in Brazil. It has been deposited in the collection of the Yeast Division of the Centraalbureau voor Schimmelcultures, Utrecht, The Netherlands, as strain CBS $9999^{\mathrm{T}}$ ( = NRRL Y$\left.27814^{\mathrm{T}}\right)$.

\section{Latin diagnosis of Candida saopaulonensis Ruivo, Pagnocca, Lachance et Rosa sp. nov.}

In medio liquido post dies tres ad $25^{\circ} \mathrm{C}$, cellulae globosae, singulae aut binae $(3-6.5 \times 4-7 \mu \mathrm{m})$. Cultura in agaro extracta malti et levidinis continente post 4 dies ad $25^{\circ} \mathrm{C}$, albida cremae et butyrosa. In agaro farinae Zea mays post dies 14 pseudomycelium non formatur. Asci non formantur. Glucosum fermentatur. Glucosum, galactosum, L-sorbosum, sucrosum, maltosum, trehalosum, melezitosum, D-xylosum, ethanolum, ribitolum, mannitolum, glucitolum, methyl $\alpha$-D-glucosidium, acidum gluconicum, acidum lacticum, acidum succinicum (exigue), acidum citricum (exigue), nhexadecanum, glucono- $\delta$-lactonum, 2-keto-D-gluconatum et xylitolum assimilantur. Non assimilantur cellobiosum, lactosum, melibiosum, raffinosum, inulinum, amylum solubile, L-arabinosum, D-arabinosum, D-ribosum, L-rhamnosum, Dglucosaminum, $N$-acetyl-D-glucosaminum, methanolum, glycerolum, erythritolum, galactitolum, salicinum, myoinositolum et 5-keto-D-gluconatum. L-Lysinum, ethylaminum et cadaverinum assimilantur at non natrium nitrosum nec natrium nitricum. Augmentum in $35^{\circ} \mathrm{C}$, at non $37^{\circ} \mathrm{C}$. Ureum non finditur. Diazonium caeruleum B negativum. Materia amyloidea non formantur. Crescit agaro extrato fermenti confecto 50 partes glucosi per centum raro exigue. Non crescit in medio $100 \mu \mathrm{g} \mathrm{ml}^{-1}$ cycloheximido addito. Habitat aqua et Heliconia velloziana L. Emigd. (Heliconiaceae). Typus stirps UNESP $00-99^{\mathrm{T}}$. In collectione zymotica Centraalbureau voor Schimmelcultures, Trajectum ad Rhenum, sub no. CBS $10001^{\mathrm{T}}$, typus stirps deposita est.

\section{Description of Candida saopaulonensis Ruivo, Pagnocca, Lachance \& Rosa sp. nov.}

Candida saopaulonensis (sao.pau.lo.nen'sis. N.L. fem. adj. saopaulonensis pertaining to São Paulo State, referring to the Brazilian state where the species was isolated).

In yeast extract $(0.5 \%)$ glucose $(2 \%)$ broth after 3 days at $25{ }^{\circ} \mathrm{C}$, cells occur singly or in budding pairs. Cells are spheroidal $(3-6 \cdot 5 \times 4-7 \mu \mathrm{m})$. Buds are produced multilaterally (Fig. 2c). On YM agar after 4 days at $25^{\circ} \mathrm{C}$, colonies are cream-coloured or white, low-convex, smooth and butyrous. After 2 weeks in Dalmau plate culture on cornmeal agar pseudomycelium or true mycelium is not formed. Glucose fermentation is complete after 2-5 days. The carbon compounds glucose, galactose, L-sorbose, sucrose, maltose, trehalose, melezitose, D-xylose, ethanol, ribitol, mannitol, glucitol, methyl $\alpha$-D-glucoside, D-gluconic acid, DL-lactic acid, succinic acid (weak), citric acid (weak), nhexadecane, glucono- $\delta$-lactone, 2-keto-D-gluconate and xylitol are assimilated. No growth occurs on cellobiose, lactose, melibiose, raffinose, inulin, starch, L-arabinose, D-arabinose, D-ribose, L-rhamnose, D-glucosamine, $\mathrm{N}$ acetyl-D-glucosamine, methanol, glycerol, erythritol, galactitol, salicin, myo-inositol or 5-keto-D-gluconate. Assimilation of nitrogen compounds: L-lysine, ethylamine and cadaverine are positive; nitrate and nitrite are negative. Growth at $35^{\circ} \mathrm{C}$ is positive and negative at $37^{\circ} \mathrm{C}$. Acid formation on chalk agar is positive. Urease activity and Diazonium blue $\mathrm{B}$ reaction are negative. Production of amyloid compounds is negative. Growth on $50 \%$ glucose/ yeast extract agar is weak or absent. Growth on YM agar with $10 \% \mathrm{NaCl}$ is negative. Growth in the presence of $100 \mu \mathrm{g}$ cycloheximide $\mathrm{ml}^{-1}$ is negative. Growth in the presence of $1 \%$ acetic acid is negative.

The type strain, UNESP $00-99^{\mathrm{T}}$, was isolated from water accumulated in flower bracts of Heliconia velloziana in Brazil. It has been deposited in the collection of the Yeast Division of the Centraalbureau voor Schimmelcultures, 
Utrecht, the Netherlands, as strain CBS $10001^{\mathrm{T}}$ ( = NRRL Y$27815^{\mathrm{T}}$ ).

\section{Acknowledgements}

The authors thank the UNESP-CEIS for supporting this research project and the Secretaria de Meio Ambiente (São Paulo State, Brazil) for permission to collect in the Picinguaba Nucleus at the 'Serra do Mar' State Park (Process. SMA: 42.364/99). This work was funded by the Conselho Nacional de Desenvolvimento Cientifico e Tecnológico (CNPq), Fundação de Amparo à Pesquisa do Estado de Minas Gerais (FAPEMIG, process no. CBB - 378/04) and the Natural Science and Engineering Research Council of Canada (M.-A. L.).

\section{References}

Boekhout, T., Robert, V., Smith, M. Th. \& 9 other authors (2002). Yeasts of the World. Morphology, Physiology, Sequences and Identification. Biodiversity Center of ETI, Multimedia Interactive Software. Windows version 2.0. Heidelberg: Springer.

Citadini-Zanette, V. \& Baptista, L. R. M. (1989). Vegetação herbácea terrícola de uma comunidade florestal em Limoeiro, município de Torres, RS, Brasil. Bol Inst Bioc 45, 1-87.

Dahlgren, R. M. T., Clifford, H. T. \& Yeo, P. F. (1985). The Families of the Monocotyledons: Structure, Evolution and Taxonomy. Berlin: Springer.

Hong, S. G., Chun, J., Oh, W. H. \& Bae, K. S. (2001). Metschnikowia koreensis sp. nov., a novel yeast species isolated from flowers in Korea. Int J Syst Evol Microbiol 51, 1927-1931.

Kress, W. J. (1985). Bat pollination of an Old World Heliconia. Biotropica 17, 302-308.

Kress, W. J. (1990). The diversity and distribution of Heliconia (Heliconiaceae) in Brazil. Acta Bot Bras 4, 159-167.

Kurtzman, C. P. \& Fell, J. W. (editors) (1998). The Yeasts - a Taxonomic Study, 4th edn. Amsterdam: Elsevier.
Kurtzman, C. P. \& Robnett, C. J. (1998). Identification and phylogeny of ascomycetous yeasts from analysis of nuclear large subunit (26S) ribosomal DNA partial sequences. Antonie van Leeuwenhoek 73, 331-371.

Lachance, M. A., Bowles, J. M., Starmer, W. T. \& Barker, J. S. F. (1999). Kodamaea kakaduensis and Candida tolerans, two new ascomycetous yeast species from Australian Hibiscus flowers. Can J Microbiol 45, 172-177.

Mello-Filho, L. E. (1975). O gênero Heliconia na Flora Fluminensis de Frei José Mariano da Conceição Vellozo. Rev Bras Biol 35, 331-337.

O'Donnell, K. (1993). Fusarium and its near relatives. In The Fungal Holomorph: Mitotic and Pleomorphic Speciation in Fungal Systematics, pp. 225-233. Edited by D. R. Reynolds \& J. W. Taylor. Wallingford, UK: CAB International.

Rosa, C. A., Lachance, M.-A., Starmer, W. T., Barker, J. S. F., Bowles, J. M. \& Schlag-Edler, B. (1999). Kodamaea nitidulidarum, Candida restingae and Kodamaea anthophila, three new related yeast species from ephemeral flowers. Int J Syst Bacteriol 49, 309-318.

Santos, E. (1978). Revisão das espécies do gênero Heliconia L. (Musaceae s.l.) espontâneas na região fluminense. Rodriguesia 30, 99-201.

Schnittler, M. \& Stephenson, S. L. (2002). Inflorescences of neotropical herbs as a newly discovered microhabitat for myxomycetes. Mycologia 94, 6-20.

Stiles, F. G. (1975). Ecology, flowering phenology, and hummingbird pollination of some Costa Rican Heliconia species. Ecology 56, 285-301.

Tomlinson, P. B. (1969). Commelinales-Zingiberales. In Anatomy of the Monocotyledons - III, pp. 295-324. Edited by C. R. Metcalfe. Oxford: Oxford University Press.

Trindade, R. C., Resende, M. A., Silva, C. M. \& Rosa, C. A. (2002). Yeasts associated with fresh and frozen pulps of Brazilian tropical fruits. Syst Appl Microbiol 25, 294-300.

Yarrow, D. (1998). Methods for the isolation and identification of yeasts. In The Yeasts - a Taxonomic Study, 4th edn, pp. 77-100. Edited by C. P. Kurtzman \& J. W. Fell. Amsterdam: Elsevier. 